\title{
A Study on Effectiveness of Internal Control System in Selected Banks in Saudi Arabia
}

\author{
Raj Bahadur Sharma ${ }^{1}$ and Nabil Ahmed M. Senan ${ }^{2}$ \\ ${ }^{1 \& 2}$ Assistant Professor, Department of Accounting, College of Business Administration \\ Prince Sattam bin Abdul Aziz University, Al Kharj, Kingdom of Saudi Arabia \\ E-Mail: rbsharmaji@gmail.com, nabil_senan@yahoo.com
}

\begin{abstract}
The study is to attempt to examine effectiveness of internal control system in selected Saudi Banks in Saudi Arabia. The effectiveness of internal control depends and interrelated to five components viz., Control Environment, Risk Assessment, Accounting Information System and Communication System, Control Activities, and SelfMonitoring. These components derived from management and integrated with the management process. Although the components are applicable to all banks, small and medium, sized banks can apply them separately on a large scale. Its control can be less formal and less structured, yet a small bank can control effective internal controls. The study concluded that the Banks in Saudi Arabia have satisfactory internal control system. The Al Rajhi bank has top most internal control system in selected banks. It recommended that there still need to improve in control environment, risk assessment and communication system in banks. The study statistically proved that there is significant difference in effectiveness of Internal Controls in the Selected Saudi Banks.

Keywords: Internal Control, Control Environment, Risk Assessment, Self-Monitoring
\end{abstract}

\section{INTRODUCTION}

The Internal Control System (ICS) is a critical component of audit tool that could provide a strong and competent working condition. Audit performs is a systematic and independent examination of data, records, performance and returns of the companies for specific purposes. An effective internal control is a framework that alone can achieve its hierarchical objectives. ICS could involve the complete management control system used by managements to continue the Company's businesses in an organized and efficient manner. This is accomplished by automatic control through internal inspections, audits and the like. A model for an 'effective' ICS was developed in 1992 by the Committee of Sponsoring Organizations of Tread way Commission (COSO). The Committee included the following five components to achieve the objectives.

1. Control Environment

2. Risk Assessment

3. Accounting Information System and Communication System

4. Control Activities

5. Self Assessments

The emphasis of ICS is on reliable and accurate information. The system is also capable of taking care of the security of the assets and simultaneously following the management policies. The present study attempts to examine the effectiveness of ICS in the Saudi Banking Sector. With this aspect in mind the objectives of the study are set as under:

1. To evaluate the effectiveness of ICS in selected banks in Saudi Arabia.

2. To find out the most effecting factors of ICS in Saudi Banks.

Based on the objectives and with the intension of studying the effectiveness of ICs the following research questions have been identified by the researcher:

1. Does the control environment affect the effectiveness of the Bank's internal control?

2. Does the control activity affect the effectiveness of the Bank's internal control?

The hypotheses formulated for the study is:

$H_{0 I}$ : There Is No Difference in the Effectiveness of Internal Control System (ICS) Among the Selected Banks in Saudi Arabia.

The data for the present work, which focuses on the effectiveness of ICS of selected banks in Saudi Arabia, was collected through questionnaire using convenient sampling method. Based on the popularity, the following banks were selected for the study (a) Al Rajhi Bank (b) Alinma Bank (c) Riyad Bank (d) SABB (e) Others. This research problem has been identified by the researchers as ICS is very vital to banking industry. This is because banks are engaged in broader financial, economic and social roles. Further, all private sector organizations must invariable have a strong ICS in position if it is to achieve its objectives. The work also addresses the relationship between ICS and internal control components towards financial performances of the banking sector.

\section{REVIEW OF LITERATURE}

There is no dearth for literature regarding various aspects of ICS, and it's a widely researched topic. Studies have originated from almost all parts of the globe. A few indicative studies from different parts of the world are presented in the following sections 


\section{A. Studies from Europe}

A number of studies have been conducted in various parts of Europe. In a study conducted in UK by Spira and Page (2003), using a sociological perspective, identified the reinvention of internal control and the changing role of internal audit. The focus of the study was mostly on the risk and its conceptualization in internal control and risk management in the corporate governance arena. They found that there were ample opportunities for the appropriation of risk and its management by those wishing to advance their own interests. Allegrin, D'Onza, Melville and Sarens (2008) reviewed the internal auditing based on available European literature. It aimed at documenting the changes in the internal auditing functions, based on the shifts in global business practices. Their results showed that the practices in Europe were similar to that of the US.

The effectiveness of ICS of Greek banking sector was that matter of study by Karagiorgos, Drogalas and Dimou (2010). The study underlined the requirement of a "wellorganized internal control system". They concluded that such a system ensured safe and sound institutional credit activity. Internal control saves credit institution's activities. The attitude of Greek banks towards application of "riskbased" approach was the matter studied by Koutoupis and Tsamis (2009). They found that international regulations were capable of reducing the risks. Internal auditing should give due and adequate care towards the "risk-based" approach.

Karagiorgos, Drogalas and Giovanis (2011) based their study on the evaluation of the effectiveness of internal audit in Greek hospitality industry - Hotel business. They aimed at presenting empirical evidences about the interactions between various components of internal control system and performance of internal auditing system. The findings suggested that the various components of internal audit system are of vital importance for its effectiveness. This has the capability to influence the survival and success of the business unit.

\section{B. Studies from Africa}

El Hadi, Khaled and El Bashary (2006) based their study on the role of ICS in the promotion of operational efficiency in Sudanese banking sector. The study aimed to highlight the importance and the various characteristics of ICS in different establishments. They averred that in the event of any weakness in the organizational structure, there would be difficulties in having proper ICS. Mostaf, and Halim (2007) evaluated the methods and tools of ICS in the Sudanese banking system. It identified the methods and tools of ICS and the scientific basics of Auditing. The study showed that using ICS lead to the achievement of banking safety.

A study by Olatunji (2009), which focused on the impact of ICS in banking industry in Nigeria, verified its effectiveness and efficiency. They found that ICS is the best control measure that could prevent and detect frauds in the banking sector. Internal control prevents and detections of frauds". Saleh, Khalid Mohammed Ahmed Mohammed (2010) studied the role of ICS in reducing the risks associated with auditing in the Sudanese banking sector. The study adopted the perspective of the auditors. Results showed that the greater the risk of control resulting from a defective ICS, the greater the risk with respect to audit. Application of the rules of corporate governance in Sudanese banking sector was the matter of research by Saleh and Siddiq (2008). The impact of governance on ICS was the main focus. They found that application of governance in the sector increased the effectiveness of the ICS.

Mihret and Wondim (2007) studied the internal audit effectiveness on the Ethiopian public sector. It also aimed at identifying the various factors that could impact the effectiveness of internal audit services. The result highlighted that internal audit effectiveness is strongly influenced by internal audit quality and management support. However, the organizational setting and the various auditee attributes failed to have any impact on the audit effectiveness.

\section{Studies from US}

Hass, Abdul mohammadi and Burnaby (2006) reviewed the US literature. They intended to document how the internal audit function is changing in response to the shifts in global business practices. They concluded that more work is required to be done to prepare internal auditors to inculcate in them certain expanded set of skills and knowledge required to perform future audits.

\section{Studies from Asia}

Siddiqui and Podder (2002) examined the effectiveness of financial audit of banking companies of Bangladesh. They analyzed the audited financial statements of 14 banking companies. The study found that seven companies overstated their profits. The research identified the need for independence, objectivity and competence of the auditors who are assigned to audit the banking companies. Kerzan (2014) based their study on the contribution of internal auditing in the application of governance in Syrian public and private sector banks. It aimed at clarifying if there are differences with respect to the contribution of application between private sector banks and public sector banks. The study concluded a positive connection between internal audit and corporate governance.

ICS and internal auditing practices of Malaysian companies were the matter of examination by Fadzil, Haron, and Jantan (2005). The study aimed at determining whether the internal audit departments complied with the Standards for the Professional Practice of Internal Auditors (SPPIA). It also aimed at determining whether compliance to SPPIA will affect the quality of ICS. The result pointed to the direction that management of internal audit department, 
professional proficiency, objectivity and review, significantly influence the monitoring aspect of ICS. Krishnan (2005) studied the Audit Committee quality and its relation with ICS in Indian companies. The results indicated that Committees with adequate financial expertise were significantly less likely to be associated with the incidence of ICS problems. Al-Bahaidi and Essam (2014) studied the banks operating in Gaza Strip. The study focused on the effectiveness of the ICS under the electronic accounting information systems. They found that the use of ICS had significant impact on the effectiveness of Electronic Accounting Information Systems in banks of the region.

A few studies have been conducted in Saudi Arabia too. The most prominent among them is the study by Alzeban and $G$ william (2014) in Saudi public sector. The study focused on the factors that affect internal audit effectiveness in the country. The results suggest that management support for Internal Audit Effectiveness drives perceived effectiveness of the internal audit function from both management's and the internal auditors' perspective.

Badara, M. A. S., \& Saidin, S. Z. (2013 Study revealed that, "The study based on the Impact of the effective internal control system on the internal audit effectiveness at local government level. It aimed to examine the relationship between effective internal control system and internal audit effectiveness at local government level. The result concluded that effective internal control system can influence the effectiveness of internal auditors at local level". Petrovits, C., Shakespeare, C., \& Shih, A. (2011 Study revealed that, "The study based on the causes and consequences of internal control problems in nonprofit organizations. It aimed to examine the causes and consequences of internal control deficiencies in the nonprofit sector using a sample of 27,495 public charities from 1999 to 2007. The results suggest that donors and government agencies react either directly or indirectly to internal control information".

Palmer, P. (1996 Study revealed that, "The study based on Internal audit in charities. It aimed to identify how internal auditing will spread in charities. The result that internal auditing will not be more widespread in larger charities unless an expectations gap is overcome and an educational initiative coupled with recommendations from the regulator is made".

\section{METHODOLOGY}

To accomplish the objectives of the study exploratory form of research was used. The design of the study was descriptive research method. Further, both qualitative and quantitative methods were applied throughout the study, as both primary and secondary data was used for the study. Primary data for the study was collected through Questionnaire. Other required information was collected from various books, websites and published research works.
The qualitative data was analyzed using various statistical techniques, the details of which are presented in the following sections.

\section{A. Tool Used For Data Collection}

A questionnaire prepared for the purpose was used to collect data for the study. The questionnaire consisted of two parts. Part A of the Questionnaire includes demographic questions of respondents and part B consists with questions related to five components of internal controls. The sample for the study consisted of 90 respondents chosen from executives of various banks, the details of which are presented in Table I.

TABLE I NUMBER OF RESPONDENTS

\begin{tabular}{|l|c|c|}
\hline \multicolumn{1}{|c|}{ Bank } & No. of sample & Per cent \\
\hline Al Rajhi Bank & 24 & 26.7 \\
\hline Alinma Bank & 16 & 17.8 \\
\hline Riyad Bank & 18 & 20 \\
\hline SABB & 11 & 12.2 \\
\hline Others & 21 & 23.3 \\
\hline
\end{tabular}

\section{B. Reliability Test}

The reliability of the questionnaire used for the study was assessed by Cronbach's alpha. The result of the analysis is presented in Table II. As shown in the Table II, the alpha values ranged from 0.788 to 0.920 . Thus it can be found that all the components have obtained the acceptable ruleof- the-thump level of alpha of 0.70 . This indicates that the scales used for the study has the qualification of being reliable.

TABLE II RELIABILITY TESTING

\begin{tabular}{|l|c|}
\hline \multicolumn{1}{|c|}{ Internal Control Components } & Cronbach's Alpha \\
\hline Control Environment & .848 \\
\hline Risk Assessment & .810 \\
\hline Control Activities & .838 \\
\hline $\begin{array}{l}\text { Accounting, Information \& } \\
\text { Communication System }\end{array}$ & .788 \\
\hline Self-Assessment or Monitoring & .920 \\
\hline
\end{tabular}

\section{Descriptive Statistics}

The detailed demographics of the sample are presented in Table III. Majority of the sample ( $80 \%$ were males). Maximum number of respondents (43) was in the 30 to 40 years age group, with minimum being in 40 and above age group (7). The education level of the respondents also varied. While $60(76.7 \%)$ were bachelor degree holders, one each were master and $\mathrm{PhD}$ degree holders. The balance (19-21.1\%) were diploma holders. There was wide variation with respect to years of experience. The maximum number of respondents $(45-50 \%)$ was in the one to four years category, followed by four to eight years (25). 
The least number of respondents belonged to the less than one category. Only two were in the above 10 years category. There existed diversity with respect to income levels too. The maximum respondents (53) were in the SAR 5000 to 10000 category; followed by above SAR 10000 (30). There were total of seven respondents in the less than SAR 5000 category. Based on the diversity in terms of the demographics, it can be considered that the sample is representative in nature.

TABLE III DEMOgRAPHics Of THE SAMPLE

\begin{tabular}{|c|c|c|c|}
\hline Variables & Category & $\begin{array}{c}\text { No. of } \\
\text { Respondents }\end{array}$ & Percentage \\
\hline \multirow{2}{*}{ Gender } & Male & 80.0 & 80.0 \\
\hline & Female & 20.0 & 20.0 \\
\hline \multirow{3}{*}{ Age } & $18-30$ years & 40 & 44.4 \\
\hline & $30-40$ years & 43 & 47.8 \\
\hline & 40-and above & 7 & 7.8 \\
\hline \multirow{4}{*}{$\begin{array}{l}\text { Education } \\
\text { wise }\end{array}$} & $\begin{array}{l}\text { Bachelor } \\
\text { Degree }\end{array}$ & 69 & 76.7 \\
\hline & Master Degree & 1 & 1.1 \\
\hline & Doctorate & 1 & 1.1 \\
\hline & $\begin{array}{c}\text { Other- } \\
\text { Diploma }\end{array}$ & 19 & 21.1 \\
\hline \multirow{5}{*}{$\begin{array}{l}\text { Experience } \\
\text { Wise }\end{array}$} & Below <1 year & 3 & 3.3 \\
\hline & $1-4$ years & 45 & 50 \\
\hline & $4-8$ years & 25 & 27.8 \\
\hline & $8-10$ years & 15 & 16.7 \\
\hline & $\begin{array}{c}\text { Above }>10 \\
\text { years }\end{array}$ & 2 & 2.2 \\
\hline \multirow{4}{*}{$\begin{array}{l}\text { Income } \\
\text { Group Wise }\end{array}$} & $\begin{array}{l}\text { Below } 2000 \\
\text { SAR }\end{array}$ & 1 & 1.1 \\
\hline & $\begin{array}{c}2000 \text { to } 5000 \\
\text { SAR }\end{array}$ & 6 & 6.7 \\
\hline & $\begin{array}{c}5000-10000 \\
\text { SAR }\end{array}$ & 53 & 58.9 \\
\hline & $\begin{array}{c}\text { Above } 10000 \\
\text { SAR }\end{array}$ & 30 & 33.3 \\
\hline
\end{tabular}

\section{ANALYSIS OF INTERNAL CONTROL COMPONENTS IN SAUDI BANKING SECTOR}

\section{A. Control Environment}

This component was related to the attitude of management and their employees towards the need for internal control. If employees take the controls seriously, it would enhance the robustness of the system of internal control.

Table IV shows the responses of questions related to 'Control Environment'. It shows the mean score of subcomponents of 'Control Environment'. It indicated that $\mathrm{Al}$ Rajhi Bank 1.4; Alinma Bank 1.0, Riyadh Bank 1.2, SABB 1.5 and other banks 1.2. The result indicated that $\mathrm{Al}$ rajhi and SABB Bank 'Control Environment' is excellent as compare to other banks.
TABLE IV CONTROL ENVIRONMENT

\begin{tabular}{|l|c|c|c|c|c|}
\hline Questions & $\begin{array}{c}\text { Al Rajhi } \\
\text { Bank }\end{array}$ & $\begin{array}{c}\text { Alinma } \\
\text { Bank }\end{array}$ & $\begin{array}{c}\text { Riyad } \\
\text { Bank }\end{array}$ & SABB & Others \\
\hline Q1 & 1.4 & 1.0 & 1.0 & 1.2 & 1.0 \\
\hline Q2 & 1.4 & 1.0 & 1.0 & 1.4 & 1.0 \\
\hline Q3 & 1.5 & 1.0 & 1.0 & 1.4 & 1.0 \\
\hline Q4 & 1.5 & 1.1 & 1.1 & 1.4 & 1.2 \\
\hline Q5 & 1.4 & 1.0 & 1.2 & 1.4 & 1.1 \\
\hline Q6 & 1.3 & 1.1 & 1.3 & 1.7 & 1.4 \\
\hline Q7 & 1.3 & 1.0 & 1.3 & 1.7 & 1.2 \\
\hline Q8 & 1.5 & 1.0 & 1.3 & 1.4 & 1.2 \\
\hline Q9 & 1.5 & 1.0 & 1.3 & 1.7 & 1.3 \\
\hline Q10 & 1.5 & 1.0 & 1.2 & 1.4 & 1.2 \\
\hline Mean & 1.4 & 1.0 & 1.2 & 1.5 & 1.2 \\
\hline
\end{tabular}

\section{B. Risk Assessment}

Risk Assessment is the process of reviewing the Critical risk in business. It is assess on regular basis.

TABLE V RISK ASSESSMENT

\begin{tabular}{|l|c|c|c|c|c|}
\hline Questions & $\begin{array}{c}\text { Al Rajhi } \\
\text { Bank }\end{array}$ & $\begin{array}{c}\text { Alinma } \\
\text { Bank }\end{array}$ & $\begin{array}{c}\text { Riyad } \\
\text { Bank }\end{array}$ & SABB & Others \\
\hline Q11 & 1.6 & 1.1 & 1.2 & 1.2 & 1.2 \\
\hline Q12 & 1.6 & 1.0 & 1.3 & 1.4 & 1.3 \\
\hline Q13 & 1.8 & 1.1 & 1.4 & 1.5 & 1.2 \\
\hline Q14 & 1.3 & 1.2 & 1.2 & 1.5 & 1.3 \\
\hline Q15 & 1.4 & 1.2 & 1.1 & 1.2 & 1.2 \\
\hline Q16 & 1.2 & 1.1 & 1.1 & 1.2 & 1.1 \\
\hline Mean & 1.5 & 1.1 & 1.2 & 1.3 & 1.2 \\
\hline
\end{tabular}

Table $\mathrm{V}$ shows the responses of questions related to 'Risk Assessment'. It shows mean score of risk sub components. It indicates that Al Rajhi Bank 1.5; Alinma Bank 1.1, Al Riyadh Bank 1.2, SABB 1.3 and other banks 1.2. The result concludes that $\mathrm{Al}$ Rajhi and $\mathrm{SABB}$ are regularly reviewing 'Risk Assessment' as compare to other banks.

\section{Control Activities}

This competent of Internal Control is use of accounting systems, information technology, and other resources to ensure that appropriate controls are put in place and operating properly.

Table VI shows the responses on 'Control Activities:' It shows the means score of 'Control Activities of Al Rajhi Bank 1.4; Alinma Bank 1.2, al Riyadh Bank 1.3, SABB 1.2 and other banks 1.2. The result indicated that Al Rajhi and al Riyadh Bank has good 'Control Activities:' as compare to others. 
TABLE Vi CONTROL ACTIVITIES

\begin{tabular}{|l|c|c|c|c|c|}
\hline Questions & $\begin{array}{c}\text { Al Rajhi } \\
\text { Bank }\end{array}$ & $\begin{array}{c}\text { Alinma } \\
\text { Bank }\end{array}$ & $\begin{array}{c}\text { Riyad } \\
\text { Bank }\end{array}$ & SABB & Others \\
\hline Q17 & 1.3 & 1.1 & 1.2 & 1.2 & 1.2 \\
\hline Q18 & 1.2 & 1.0 & 1.2 & 1.2 & 1.3 \\
\hline Q19 & 1.3 & 1.1 & 1.1 & 1.0 & 1.2 \\
\hline Q20 & 1.5 & 1.1 & 1.2 & 1.0 & 1.2 \\
\hline Q21 & 1.3 & 1.1 & 1.4 & 1.2 & 1.1 \\
\hline Q22 & 1.3 & 1.3 & 1.3 & 1.2 & 1.1 \\
\hline Q23 & 1.5 & 1.3 & 1.3 & 1.5 & 1.1 \\
\hline Q24 & 1.8 & 1.1 & 1.2 & 1.2 & 1.2 \\
\hline Q25 & 1.7 & 1.3 & 1.2 & 1.2 & 1.1 \\
\hline Mean & 1.4 & 1.2 & 1.3 & 1.2 & 1.2 \\
\hline
\end{tabular}

\section{Accounting, Information and Communication Systems}

The information system relevant to financial objective includes all the procedure and records. These components communicate to the management about information and communication. The amount of information communicated should be appropriate to the need of the recipients.

TABLE VII ACCOUNTING, INFORMATION AND COMMUNICATION SYSTEMS

\begin{tabular}{|l|c|c|c|c|c|}
\hline Questions & $\begin{array}{c}\text { Al Rajhi } \\
\text { Bank }\end{array}$ & $\begin{array}{c}\text { Alinma } \\
\text { Bank }\end{array}$ & $\begin{array}{c}\text { Riyad } \\
\text { Bank }\end{array}$ & SABB & Others \\
\hline Q26 & 1.5 & 1.3 & 1.2 & 1.2 & 1.1 \\
\hline Q27 & 1.4 & 1.1 & 1.6 & 1.0 & 1.1 \\
\hline Q28 & 1.6 & 1.1 & 1.6 & 1.4 & 1.1 \\
\hline Q29 & 1.5 & 1.4 & 1.6 & 1.2 & 1.1 \\
\hline Q30 & 1.4 & 1.4 & 1.4 & 1.2 & 1.1 \\
\hline Mean & 1.5 & 1.3 & 1.5 & 1.2 & 1.1 \\
\hline
\end{tabular}

Table VII shows the responses on 'Accounting, Information and Communication systems in different banks. It shows that 'Accounting, Information and Communication system' which is a one segment of internal control, the mean score of the components shows that Al Rajhi Bank 1.5; Alinma Bank 1.3, Riyadh Bank 1.5, SABB 1.2 and other banks 1.1. The result indicated that Al Rajhi and al Riyadh Bank has strong 'Accounting, Information and Communication system:' as compare to others.

\section{E. Self-Assessment or Monitoring}

This component involves understanding the monitoring system of management. This is the set of processes used by management to examine and assess whether its internal controls are functioning properly.

Table VIII shows the responses of 'Self-Assessment or monitoring'. The mean score of the component shows that Al Rajhi Bank 1.6; Alinma Bank 1.2, Riyadh Bank 1.3, SABB 1.1 and others 1.3. The result indicated that $\mathrm{Al}$ rajhi Bank has excellent in monitoring as compare to other banks.

TABLE VIII SELF-ASSESSMENT OR MONITORING

\begin{tabular}{|l|c|c|c|c|c|}
\hline Questions & $\begin{array}{c}\text { Al Rajhi } \\
\text { Bank }\end{array}$ & $\begin{array}{c}\text { Alinma } \\
\text { Bank }\end{array}$ & $\begin{array}{c}\text { Riyad } \\
\text { Bank }\end{array}$ & SABB & Others \\
\hline Q31 & 1.6 & 1.4 & 1.3 & 1.2 & 1.2 \\
\hline Q32 & 1.7 & 1.3 & 1.3 & 1.4 & 1.3 \\
\hline Q33 & 1.4 & 1.5 & 1.3 & 1.0 & 1.3 \\
\hline Q34 & 1.7 & 1.2 & 1.3 & 1.0 & 1.4 \\
\hline Q35 & 1.5 & 1.1 & 1.3 & 1.0 & 1.3 \\
\hline Q36 & 1.7 & 1.3 & 1.3 & 1.0 & 1.3 \\
\hline Q37 & 1.7 & 1.1 & 1.3 & 1.0 & 1.3 \\
\hline Q38 & 1.6 & 1.1 & 1.2 & 1.0 & 1.2 \\
\hline Q39 & 1.7 & 1.3 & 1.3 & 1.2 & 1.4 \\
\hline Mean & 1.6 & 1.2 & 1.3 & 1.1 & 1.3 \\
\hline
\end{tabular}

\section{TESTING OF HYPOTHESIS}

Effective internal control can mitigate risk and maximum output. The strong internal control can keep banks by helping to achieve safeguarding assets, ensuring reliable financial reporting, maintaining compliance, accomplishing operational efficiency etc. Table IX shows the overall analysis of each internal control competent in selected banks in Saudi Arabia.

It is found that in the Saudi banking industry the internal control system is very effective and satisfactory. Al Rajhi bank and Riyadh Bank has the strongest internal control system in ranking.

TABLE IX MEAN SCORE OF COMPONENTS

\begin{tabular}{|c|c|c|c|c|c|c|c|c|}
\hline Banks & $\begin{array}{c}\text { Control } \\
\text { Environment }\end{array}$ & $\begin{array}{c}\text { Risk } \\
\text { Assessment }\end{array}$ & $\begin{array}{c}\text { Accounting, Information } \\
\text { and Communication } \\
\text { system }\end{array}$ & $\begin{array}{c}\text { Control } \\
\text { Activities }\end{array}$ & $\begin{array}{c}\text { Self } \\
\text { Assessment }\end{array}$ & Mean & $\begin{array}{l}\text { Std. } \\
\text { Dev }\end{array}$ & Rank \\
\hline Al Rajhi Bank & 1.4 & 1.5 & 1.4 & 1.5 & 1.6 & 1.48 & 0.083 & 1 \\
\hline Alinma Bank & 1.0 & 1.1 & 1.2 & 1.3 & 1.2 & 1.15 & 0.11 & 5 \\
\hline Riyad Bank & 1.2 & 1.2 & 1.3 & 1.5 & 1.3 & 1.29 & 0.12 & 2 \\
\hline
\end{tabular}


TABLE X TEST OF HOMOgENEITY OF VARIANCES INTERNAL CONTROL

\begin{tabular}{|c|c|c|c|}
\hline Levene Statistic & df1 & df2 & Sig. \\
\hline 1.344 & 4 & 85 & .260 \\
\hline
\end{tabular}

The above table $\mathrm{X}$ shows the homogeneity of data. For checking homogeneity of Data Levene test has been performed and found that $\mathrm{p}=.260(\mathrm{p}>.05)$. It shows that data are homogenous.

TABLE Xi ANALYSIS OF VARIANCE

\begin{tabular}{|l|c|c|c|c|c|}
\hline \multicolumn{7}{|c|}{ ANOVA } \\
\hline & $\begin{array}{c}\text { Sum of } \\
\text { Squares }\end{array}$ & df & $\begin{array}{c}\text { Mean } \\
\text { Square }\end{array}$ & F & Sig. \\
\hline $\begin{array}{l}\text { Between } \\
\text { Groups }\end{array}$ & 84.670 & 4 & 21.167 & 2.806 & .031 \\
\hline $\begin{array}{l}\text { Within } \\
\text { Groups }\end{array}$ & 641.108 & 85 & 7.542 & & \\
\hline Total & 725.778 & 89 & & & \\
\hline
\end{tabular}

There is significant difference in the Internal Controls of Selected Saudi Banks, F $(4,85)=2.806, \mathrm{p}<.05$. It I $\mathrm{s}$ statistically proved that Saudi banks has its own internal control system and it varies bank to bank. It is proved that there is significant difference in effectiveness of Internal Controls in the Selected Saudi Banks.

\section{FINDINGS OF THE STUDY}

1. Control Environment: It was found that SABB bank has the strongest control environment and the Alinma bank has weak control environment.

2. Risk Assessment: It was found that the Al Rajhi bank has good capability in analysis risk assessment and Alinma Bank was weak in it.

3. Control Activities: It was found that Al Rajhi bank has control over activities and managing satisfactorily.

4. Accounting, Information and Communication Systems: It was found that Al Rajhi and Riyadh Bank follow the procedure and records. It shows that these two banks communicate to the management about information and communication.

5. Self-Assessment or Monitoring: As far as understanding the monitoring system is concern $\mathrm{Al}$ Rahih bank performed excellent as compare to other selected banks.

\section{RECOMMENDATIONS}

1. Alinma bank required to improve its internal control system. It is recommended that bank should review internal control system and develop control environment.

2. SABB bank need to review self-monitoring control activities for better internal control.

3. The internal control system of other banks apart from selected bank need to improve. It found satisfactory but not strong.

\section{CONCLUSION}

Internal control framework help to the Auditors to draw up their program to commence audit review work. Effectiveness of internal control system helps the auditor to see the duty of each staff has being defined there by quickening his work as to who to ask questions and on what to ask questions as the need arises. Internal Audit should include in the Managerial, supervision and reviews process. The study concluded that overall internal control system in selected banks found satisfactory but need to improve in control environment, risk assessment and communication system.

\section{REFERENCES}

[1] Al-Bahaidi, \& Essam. (2014). The effectiveness of the internal control system under the electronic accounting information systems is an applied study on the banks operating in the Gaza Strip.

[2] Allegrini, M., D'Onza, G., Paape, L., Melville, R., \& Sarens, G. (2006). The European literature review on internal auditing. Managerial Auditing Journal, 21(8), 845-853.

[3] Alzeban, A., \& Gwilliam, D. (2014). Factors affecting the internal audit effectiveness: A survey of the Saudi public sector. Journal of International Accounting, Auditing and Taxation, 23(2), 74-86.

[4] Karagiorgos, T., Drogalas, G., \& Giovanis, N. (2011). Evaluation of the effectiveness of internal audit in Greek Hotel Business.

[5] Badara, M. A. S., \& Saidin, S. Z. (2013). Impact of the effective internal control system on the internal audit effectiveness at local government level. Journal of Social and Development Sciences, 4(1), 16-23.

[6] El Hadi, Omar Mohamed Khaled, \& Mostafa Negm El Bashary. (2006). The role of the internal control system in promoting operational efficiency in the Sudanese banking sector (Doctoral dissertation, Sudan University of Science and Technology).

[7] Faten Hanna Kerzan. (2014). The contribution of internal auditing in the application of governance in Syrian public and private banks (comparative study).

[8] Getie Mihret, D., \& Wondim Yismaw, A. (2007). Internal audit effectiveness: an Ethiopian public sector case study. Managerial Auditing Journal, 22(5), 470-484.

[9] Hanim Fadzil, F., Haron, H., \& Jantan, M. (2005). Internal auditing practices and internal control system. Managerial Auditing Journal, 20(8), 844-866.

[10] Hass, S., Abdolmohammadi, M. J., \& Burnaby, P. (2006). The Americas literature review on internal auditing. Managerial Auditing Journal, 21(8), 835-844.

[11] Karagiorgos, T., Drogalas, G., \& Dimou, A. (2010). Effectiveness of internal control system in the Greek Bank Sector. The South European Review of Business Finance \& Accounting.

[12] Koutoupis, A. \& Tsamis, A. (2009) 'Risk based internal auditing within Greek banks: a case study approach', Journal of Management Government, 13, pp. 101-130.

[13] Krishnan, J. (2005) Audit committee quality and internal control: An empirical analysis. The accounting review, 80(2), 649-675.

[14] Mostafa, Abdel Moneim Jameel, \& Mohamed Farah Abdel Halim. (2007). Evaluation of the methods and tools of the control applied study on the Sudanese banking system (Doctoral dissertation, Sudan University of Science and Technology).

[15] Olatunji, O. C. (2009). Impact of internal control system in banking sector in Nigeria. Pakistan Journal of Social Sciences, 6(4), 181-189.

[16] Osama Mohammed Saleh, \& Supervisor - Babeker Ibrahim Siddiq. (2008). The impact of the application of the rules of corporate governance on the efficiency of the internal control system in the Sudanese banking sector (Doctoral dissertation, Sudan University of Science and Technology).

[17] Palmer, P. (1996). Internal audit in charities: a revolution still awaited. Managerial Auditing Journal, 11(6), 11-17.

[18] Petrovits, C., Shakespeare, C., \& Shih, A. (2011). The causes and consequences of internal control problems in nonprofit organizations. The Accounting Review, 86(1), 325-357. 
[19] Saleh, Khalid Mohammed Ahmed Mohammed. (2010). Internal control and its role in reducing the risk of auditing in the Sudanese banking sector from the perspective of auditors (Doctoral dissertation, Sudan University of Science and Technology).

[20] Siddiqui, J. \& Podder, J. (2002) 'Effectiveness of bank audit in Bangladesh', Managerial Auditing Journal, 17(8), 502-510.

[21] Spira, L. F., \& Page, M. (2003). Risk management: The reinvention of internal control and the changing role of internal audit. Accounting, Auditing \& Accountability Journal, 16(4), 640-661.
[22] Retrieved from http://www.alrajhibank.com.sa

[23] Retrieved from https://www.riyadbank.com

[24] Retrieved from http://www.alinma.com

[25] Retrieved from http://www.baj.com.sa

[26] Retrieved from http://www.samba.com.sa/

[27] Retrieved from https://www.anb.com.sa

[28] Retrieved from http://www.drogalas.gr/ 